\title{
Physical Properties of Persian Gulf Outflow Thermohaline Intrusion in the Oman Sea
}

\author{
Eram Ghazi1, Abbasali Aliakbari Bidokhti2 ${ }^{*}$, Mojtaba Ezam¹, Masoud Torabi Azad³, \\ Smaeyl Hassanzadeh ${ }^{4}$
}

\author{
${ }^{1}$ Department of Marine Science and Technology, Science and Research Branch, Islamic Azad University, Tehran, Iran \\ ${ }^{2}$ Institute of Geophysics, University of Tehran, Tehran, Iran \\ ${ }^{3}$ Department of Marine Science and Technology, Islamic Azad University, Tehran North Branch, Tehran, Iran \\ ${ }^{4}$ Institute of Physics, University of Isfahan, Isfahan, Iran
}

Email: ^bidokhti@ut.ac.ir

How to cite this paper: Ghazi, E., Bidokhti, A.A., Ezam, M., Azad, M.T. and Hassanzadeh, S. (2017) Physical Properties of Persian Gulf Outflow Thermohaline Intrusion in the Oman Sea. Open Journal of Marine Science, 7, 169-190.

http://dx.doi.org/10.4236/ojms.2017.71013

Received: September 18, 2016

Accepted: January 22, 2017

Published: January 25, 2017

Copyright $\odot 2017$ by authors and Scientific Research Publishing Inc. This work is licensed under the Creative Commons Attribution International License (CC BY 4.0).

http://creativecommons.org/licenses/by/4.0/

\begin{abstract}
Various CTD data obtained in the Oman Sea are analyzed to explain structural features of intrusive layering. Special attention is compensated to thermohaline intrusions observed in layers (depth ranges of $150 \mathrm{~m}$ to $450 \mathrm{~m}, 150 \mathrm{~m}$ to $350 \mathrm{~m}, 100 \mathrm{~m}$ to $350 \mathrm{~m}$ and $150 \mathrm{~m}$ and $400 \mathrm{~m}$ in the winter, spring, summer and autumn, respectively). The temperature and salinity profiles in thermohaline intrusion have sawtooth structure in all stations, while they have step structure in density field. Based on interpretations, detailed estimates of thickness are about 10 to 20 meters. The T-S diagrams show the positions of the outflow intrusion with different thicknesses and depths for all seasons in the Oman Sea. Vertical profiles of temperature and salinity show two boundaries in the upper and lower layers. They are prone to double diffusive convection. Salt fingering and diffusive convection can be seen in both the upper and lower boundaries, and salt fingering is stronger at the lower boundary. Diffusive convection also is visible from the surface to the mid-depth of the plume outflow, and the diffusive intrusion is more severe at the upper boundary than the surface and deep. The intensity of double diffusion in the bottom border is greater than the upper boundary. At the deeper parts, the stratification is completely stable. Variations of the positions of greatest salinities in different diagrams are due to changing water masses for different locations and depths and paths of intrusive flow.
\end{abstract}

\section{Keywords}

Thermohaline Intrusion, Double Diffusive Convection Salt Fingering, Persian Gulf Outflow

\section{Introduction}

The Persian Gulf is a shallow semi-enclosed sea with high evaporation rate $1.5-2 \mathrm{~m} / \mathrm{yr}$, 
is among the saltiest sea in the world, and its water flows as an inverse estuary through the Strait of Hormuz in exchanging water with the open ocean [1]. The Persian Gulf due to this strong evaporation creates a bottom outflow that enters into the Oman Sea. The Persian Gulf outflow movement down to a depth of 400 meters and a lateral boundary current at a depth of 250 meters is due to eddy activity at the offshore area. The average depth of the Persian Gulf outflow into the Oman Sea is about 250 - 400 meters [2]. The outflow of the Persian Gulf, after entering the Sea of Oman near the break of the continental shelves, starts to sink towards the deeper part and mix with the surrounding waters as it reaches a buoyancy equilibrium depth of $100-250 \mathrm{~m}$. The thermohaline properties decrease in these areas due to strong mixing of the Persian Gulf outflow into the Oman Sea by the wind variability, bottom friction, breaking of the internal waves, until a depth of neutral buoyancy, about 220 meters [3] [4].

The Persian Gulf water enters into the Sea of Oman along the continental slope, and it flows down laterally and vertically as it spreads. The intrusive thermohaline structure is created by lateral mixing associated with double diffusion. The Persian Gulf into the Oman Sea follows in a form of temperature inversion layers. The intrusive thermohaline structure in the Oman Sea is influenced by both processes double diffusion and salt fingering [5]. Interleaving intrusions can be an important mechanism in lateral and cross-frontal transmissions of heat and salt in the ocean [5]. The intrusion is usually associated with salinity and thermal inversions [6] indicate alternating layers of warm and saline, cold and fresh water. The cause of salinity and thermal inversion is lateral advection of a water mass into another one due to lateral gradient of temperature and salinity in oceanic fronts, shown by sloping of isopycnal lines [7]. [8] has investigated in some parts of the Persian Gulf and Oman Sea there are complex layered structures and inversions in vertical profiles of salinity and temperature. The strong lateral and vertical gradients create the micro structures, like temperature inversion. The intrusive layers in area of strong horizontal gradient create double diffusive convection, because of vertical temperature and salinity gradients; they are prone to convection of either the diffusive or salt finger kind [8].

The largest lateral gradient in the frontal zone, known as the thermohaline intrusion between distinct water masses with different characteristics of thermal and salinity, is able to transfer a significant volume of water between them [9]. [10] analyzed the outflow data for the Persian Gulf and used laboratory experiments on intrusions outflow created by turbulent plumes in a long box. The experiments showed that coarse vertical structure create by internal wave modes. When the laboratory plume tested both temperature and salinity components, double-diffusive convection was obvious and inclined to adjust the smooth gradients into boundaries.

These interleavings are likely created from double diffusion convection [10]. Both kinds of double diffusion convection, namely fingering and diffusive processes could create intrusive layering. In the oceanic environment, due to the differences in temperature and salinity, double-diffusive convection was often seen [11]. Vertical profiles of temperature and salinity are often characterized by zigzag pattern and different inversion which is a sign of thermohaline intrusion. It is also observed as recognizable interleaving in temperature and salinity diagrams [9] [10] [11] [12]. [13] showed that on 
average, the slope of thermohaline intrusion located between isopycnal and isohaline slopes. By consideration of differential diffusion mechanism of interleaving in Russian Arctic Region they showed that thermohaline intrusion has been observed in the regions with strong static stability. This study also confirms that the specified baroclinity effects are important in the control of slope of interleaving in differential mixing model. [12] studied thermohaline intrusion layers in the frontal zone in the North Pacific Ocean that is prone to salt fingering. They showed that salinity inversions in thermohaline structure are due to intrusive movements. [14] estimated turbulent diapycnal eddy diffusivity and small-scale mixing processes throughout the Sermilik Fjord. They concluded that double-diffusive convection in thermohaline staircase structure was between the depths $150-450 \mathrm{~m}$, in the open ocean in which the water of this Fjord enters. They explained that double diffusive intrusions play an important role in the continental shelf break waters. Heat and salinity fluxes and other parameters that are created by these lateral convection due to forcing as geothermal or climate can affect heat and salinity budgets [2].

Therefore, the focus of our investigation is to study the lateral convection across the Persian Gulf outflow front and structure of interleaving of the thermohaline front in the Oman Sea in different seasons using field data. The outline of the paper is as follows. Section 2 describes observational data of different months for years from 1992 to 1996 and the hydrography of the regain. Section 3 shows analysis of structural layers of the thermohaline intrusion for four seasons. Section 4 delineates vertical interleaving, the Turner angle and the stability ratio and T-S diagrams of water masses. Section 5 presents the conclusions.

\section{Observational Data}

The observational CTD data were obtained from ROPME (Regional Organization for the protection of the Marine Environment) expedition in January-February (leg 1) of 1992, The two Arabesque cruises (Discovery cruise 210, August-September, Discovery cruise 212, October-November 1994, the Iranian National Center for Oceanography (INCO2) in August 1995 and The Global Temperature-Salinity Project (GTSPP) in March and April 1996, as shown in Table 1. Locations of the stations are shown in Figure 1. As the data for a complete year are not available we use data of different months for years from 1992 to 1996.

\section{Analysis of Structural Layers of the Thermohaline Intrusion}

In this study, due to the unavailability of sufficient data, two seasons of winter and spring in the direction of lateral front transect and the two seasons of summer and autumn in the direction of longitudinal front transects have been analyzed. Locations of CTD measurements on hydrographic maps of the Oman Sea are shown in Figure 1: the three transects A, B and C in winter, D, E and F in spring, G, H, I in summer, L, M, N in autumn. After processing the data, the vertical and cross-sectional profiles of temperature, salinity and density in Sea of Oman are studied. Finally, all vertical profiles in the cross section profiles were low-pass filtered with a cut-off length of $20 \mathrm{~m}$ and ordered of 2 to avoid aliasing errors and also to suppress the high-frequency noises 
Table 1. List of oceanographic data collection.

\begin{tabular}{|c|c|c|c|c|c|}
\hline Cruises & $\begin{array}{c}\text { Number } \\
\text { of } \\
\text { profiles }\end{array}$ & Periods & $\begin{array}{l}\text { Collecting } \\
\text { institutions }\end{array}$ & Instruments & $\begin{array}{l}\text { Spatial } \\
\text { coverage }\end{array}$ \\
\hline $\begin{array}{c}\text { ROPME } \\
1992\end{array}$ & $\approx 300$ & $\begin{array}{c}\text { January-February } \\
\text { (leg 1) May-June } \\
(\operatorname{leg} 6)\end{array}$ & $\begin{array}{c}\text { Muscat-Jubail } \\
\text { Kuwait-Abu } \\
\text { Dhabi }\end{array}$ & CTD & $\begin{array}{c}\text { Persian } \\
\text { Gulf, Sea of } \\
\text { Oman and } \\
\text { a part of } \\
\text { Arabian Sea }\end{array}$ \\
\hline $\begin{array}{c}\text { Arabesque } \\
(210-212) \\
1994\end{array}$ & 400 & $\begin{array}{l}\text { August-September (210) } \\
\text { October-November (212) }\end{array}$ & $\begin{array}{c}\text { British } \\
\text { Oceanographic } \\
\text { Data } \\
\text { Centre-United } \\
\text { Kingdom }\end{array}$ & CTD & $\begin{array}{l}\text { Northwest } \\
\text { Indian } \\
\text { Ocean, } \\
\text { Arabian } \\
\text { Sea, Gulf of } \\
\text { Oman }\end{array}$ \\
\hline $\begin{array}{c}\text { INCO2 } \\
1995\end{array}$ & $\approx 300$ & August-September & $\begin{array}{c}\text { Iranian National } \\
\text { Center for } \\
\text { Oceanography }\end{array}$ & CTD & $\begin{array}{l}\text { Arabian } \\
\text { Sea, Gulf of } \\
\text { Oman }\end{array}$ \\
\hline $\begin{array}{l}\text { GTSPP } \\
1996\end{array}$ & 45 & March-April & USA & CTD & $\begin{array}{l}\text { Arabian } \\
\text { Sea, Gulf of } \\
\text { Oman }\end{array}$ \\
\hline
\end{tabular}

[15]-[21]. Figure 2 shows temperature, salinity and potential density filtered profiles along transect C of CTD station 3 in winter 1992.

\subsection{Intrusive Layers and Frontal Zones in Winter}

Vertical profiles and the cross-sections of temperature, salinity and potential density at three transects A, B, C in the ROPME expedition in January-February (leg 1) of 1992 in the frontal zones between the Strait of Hormuz and the Ra's Al Hamra are analyzed. The vertical and cross-section profiles of temperature, salinity and potential density along the transect $\mathrm{C}$ show that in winter intrusive structures extend over a depth of about 150 - 450 meters in the Oman Sea (Figure 3). In upper about 150 meters of Persian Gulf outflow, cold water with lower salinity overlays the warm and saline water, and stratification is favorable for the formation of the diffusive convection.

From an average depth of 250 meters down to about 450 meters, both salinity and temperature are reduced and the thermohaline stratification is compatible with salt fingering. The temperature and salinity profiles have saw-tooth structure in all stations, except in the density field where they have stepped structure. It is noteworthy that isopycnal layers have different temperature and salinity as they compensate each other in terms of density. However, since the molecular diffusion coefficient of salt (ks) is hundred times less than that for heat $(\mathrm{kt})$, thin layers while moving, lose their heat but keep their salt [16] thus, in the vertical profiles of salinity, in contrast to the vertical profiles of temperature, their developed layers stay for a longer time. It is expected that in the vertical profiles of salinity layer structure seem more pronounced. The changes of intrusive layers in temperature are smaller than that for salinity. The amplitudes and vertical scales of the intensive intrusions decrease with depth and most of the observed intrusive layers in vertical profiles have thicknesses of about $10-20$ meters. Cross-section profiles in Figure 3 show that a tongue saline in salinity cross-section, separate water 

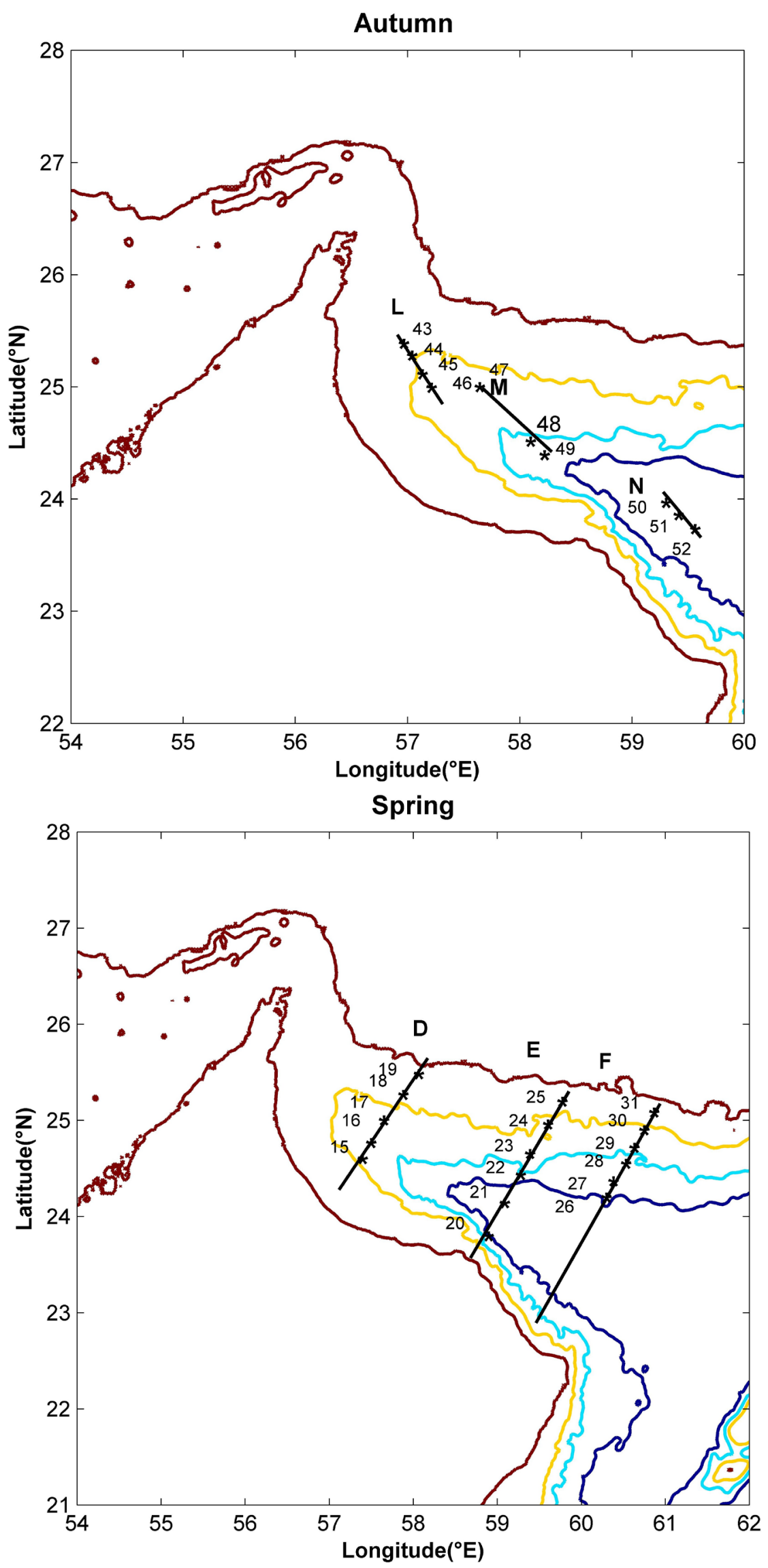

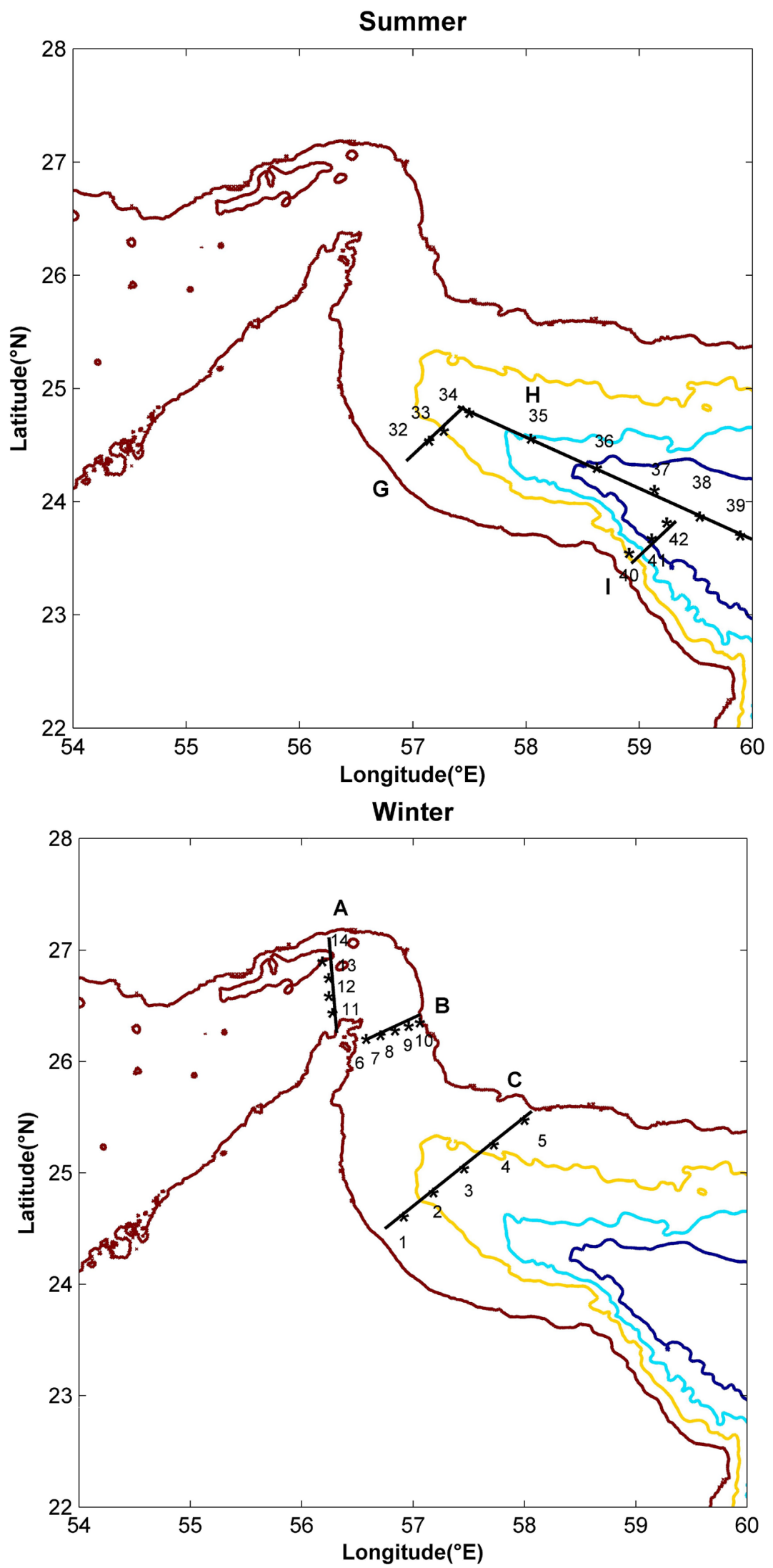

Figure 1. The bathymetry and location of CTD stations of the Gulf of Oman in four seasons. 


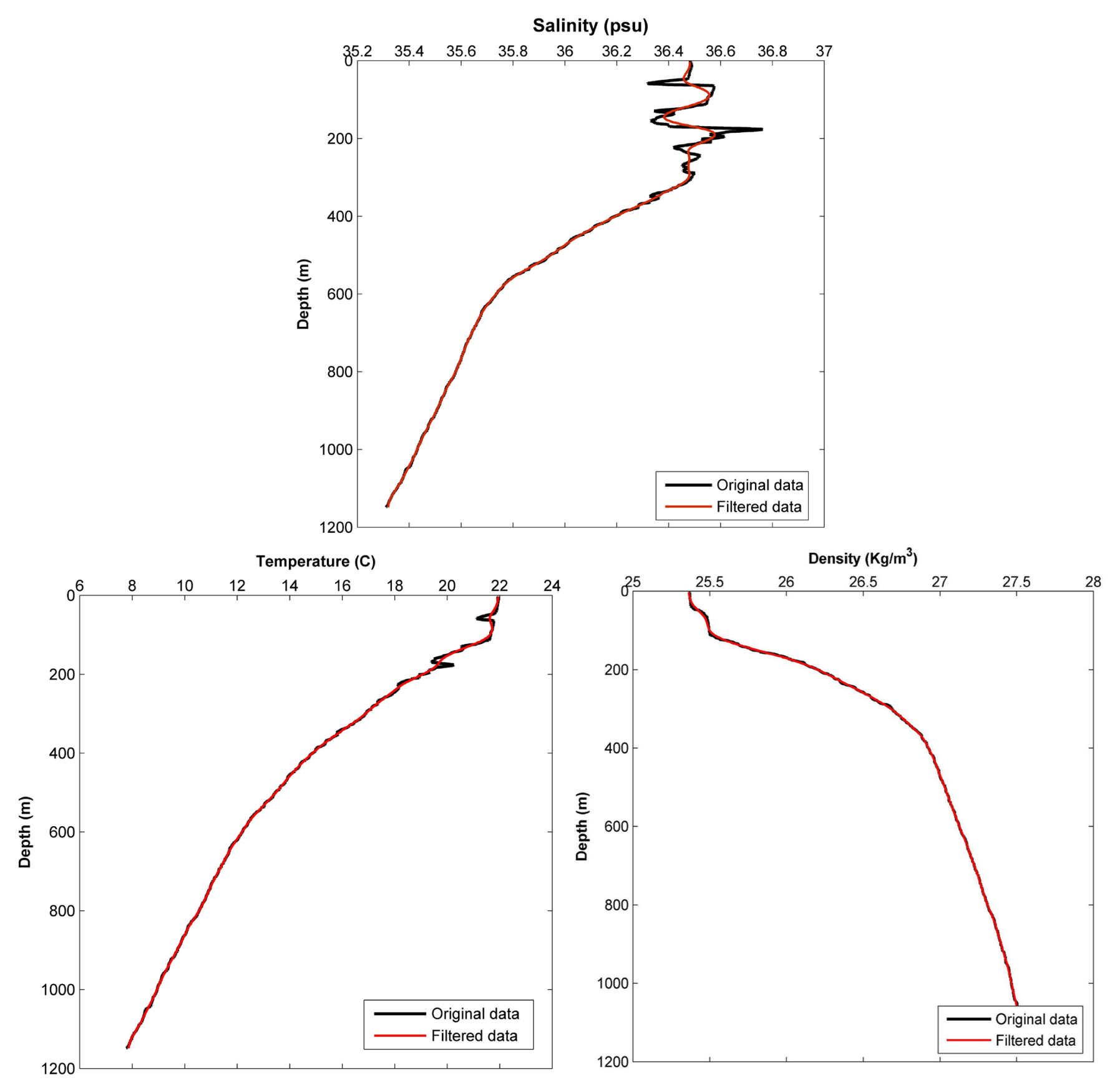

Figure 2. Temperature, salinity and potential density filtered profiles along transect C of CTD station 3 in winter 1992.

mass with salinity more than 36.6 psu from the environment, as can be seen at a depth of about $250-300 \mathrm{~m}$. This tongue saline with a temperature of about $18^{\circ} \mathrm{C}-19^{\circ} \mathrm{C}$, in the thermal cross sections, is also observed at a depth of $250 \mathrm{~m}$ as [17] have observed. Lateral cross sections in vertical sigma-t show the environmental formation of two layers of about $25.5 \mathrm{~kg} / \mathrm{m}^{3}$ in the top layer and $27.5 \mathrm{~kg} / \mathrm{m}^{3}$ in the lower layer. The temperature maximum and salinity in the winter at the studied stations reaches $21.4^{\circ} \mathrm{C}$ and 37.9 psu respectively, and the greatest salinity is at lower depth than that of the greatest temperature. A comparison between vertical and cross-section profiles shows that the most intrusive layers see in the depth range of 200 to $300 \mathrm{~m}$ in winter in a frontal zone. 

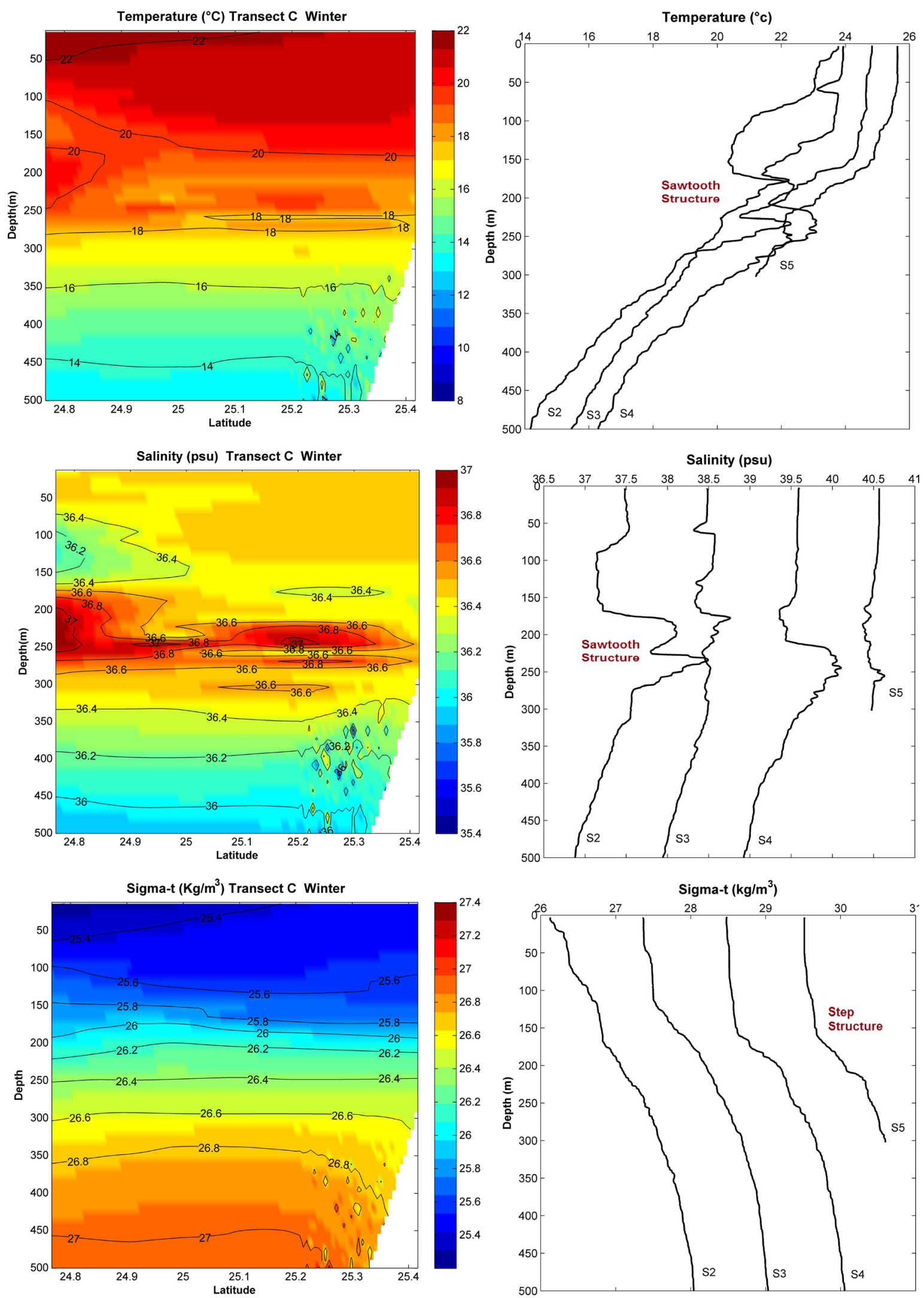

Figure 3. Vertical profiles and the cross-sections of temperature, salinity and potential density from the Persian Gulf outflow for winter 1992 from the transect C shown in Figure 1 for clarification in vertical profiles, one unit has been added to data of stations 3 , two units to data of station 4 etc. 


\subsection{Intrusive Layers in Spring}

The spring transects are D, E and F as shown in Figure 1. Figure 4 shows Vertical profiles and the cross-sections of temperature, salinity and potential density in transect D in the Global Temperature-Salinity Project (GTSPP) in March and April 1996. Intrusion layers extend from a depth of about 150 to $350 \mathrm{~m}$. These changes begin from a depth of about $150 \mathrm{~m}$, and increase to an average depth of $250 \mathrm{~m}$ in salinity profiles and decrease in temperature profiles. In upper $150 \mathrm{~m}$ of the outflow, there is cold fresh water overlaying a warm layer with a higher salt concentration and stratification is favorable for the form the diffusive convection. Maximum depth of thermohaline intrusion in salinity profiles is between 200 and 300 meters and forms at an average depth of about 300 meters, both of salinity and temperature decrease, and below the thermohaline stratification is again compatible with salt fingering convection. Thermohaline intrusion at all stations in the spring in profiles of temperature and salinity has sawtooth and in density field have step structures. The layer thickness is between 10 and 20 meters and the amplitudes and vertical scales of the intensive intrusions decrease with depth in spring. More regular intrusive layers see in the thermocline, and irregular intrusive layer in the shallow depths represent faster interaction in shallower depths. Temperature teeth are smaller than salinity teeth. So thin layer on the move, lose its warmth faster but keeps its salinity.

Cross-section profiles of temperature, salinity filtered with a cut-off length of $20 \mathrm{~m}$, along transect $\mathrm{D}$ display penetration of lateral intrusion with salinity $37 \mathrm{psu}$ and temperature $20^{\circ} \mathrm{C}$. The temperature is $24^{\circ} \mathrm{C}$ with little seasonal variation and the largest salinity of over 36.5 psu occurs at the surface water. Salinity varies by less than $1 \mathrm{psu}$ and temperature decreases $18^{\circ} \mathrm{C}$ with depth. Cross section profiles of sigma-t show formation of three layers with sigma-t values about $24.5 \mathrm{~kg} / \mathrm{m}^{3}$ in surface and $26.5 \mathrm{~kg} / \mathrm{m}^{3}$ in the middle layer and $27.5 \mathrm{~kg} / \mathrm{m}^{3}$ in dense layer on the bottom.

\subsection{Intrusive Layers in Summer}

Here profiles of transects G, H and I, for summer are analyzed, as shown in Figure 1. Figure 5 and Figure 6 display vertical profiles and the cross-sections of temperature, salinity and potential density in transect $\mathrm{H}$ in the Iranian National Center for Oceanography (INCO2) in August 1995. Thermohaline intrusion is extended from depth of 100 meters to 350 meters in the Oman Sea. In upper 100 meters of the outflow, cold water with lower salinity again overlays on the warm and saline water and stratification is favorable to the formation of the diffusive convection.

Changes start from a depth of about $100 \mathrm{~m}$ and increase to a depth averaging 200 to $250 \mathrm{~m}$ in salinity profiles and decrease in temperature profiles. From average depth of 250 meters to about 350 meters, salinity and temperature both are reduced, and thermohaline stratification is compatible with salt fingering convection.

Layer thickness is about 10 to 20 meters. Maximum temperature and salinity at the stations studied in the summer is $30^{\circ} \mathrm{C}$ and $37 \mathrm{psu}$, and the salinity maximum is situated deeper than the temperature maximum. The intrusive layers at all stations in the profile of temperature and salinity have indentations, and more layers exist in transects G, I than in transect $\mathrm{H}$. The potential density shows a step structure. In the summer, as 

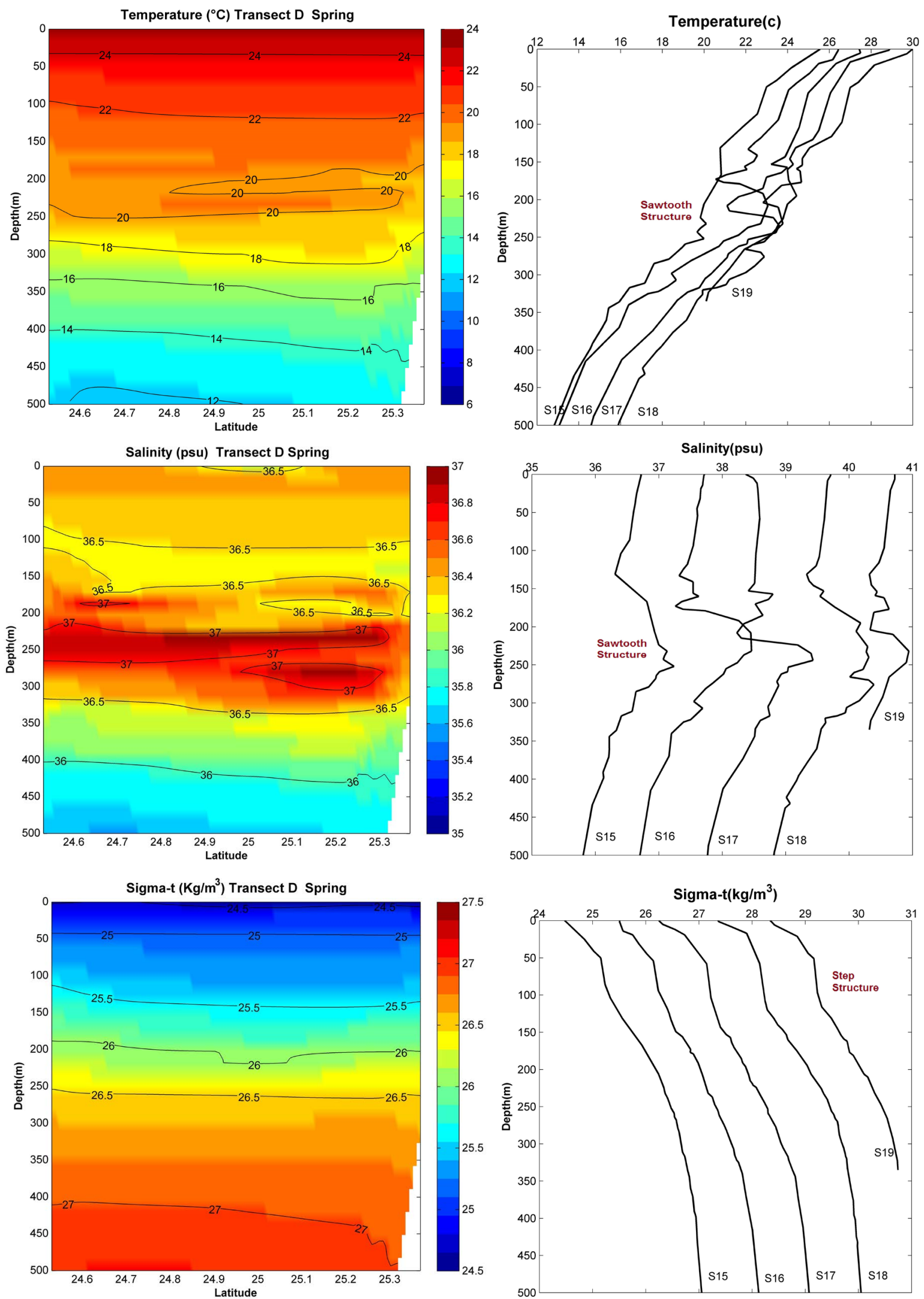

Figure 4. Vertical profiles and the cross-sections of temperature, salinity and potential density from the Persian Gulf outflow for spring 1996 from the transect D shown in Figure 1 for clarification in vertical profiles, one unit has been added to data of stations 16 , two units to data of station 17 etc. 

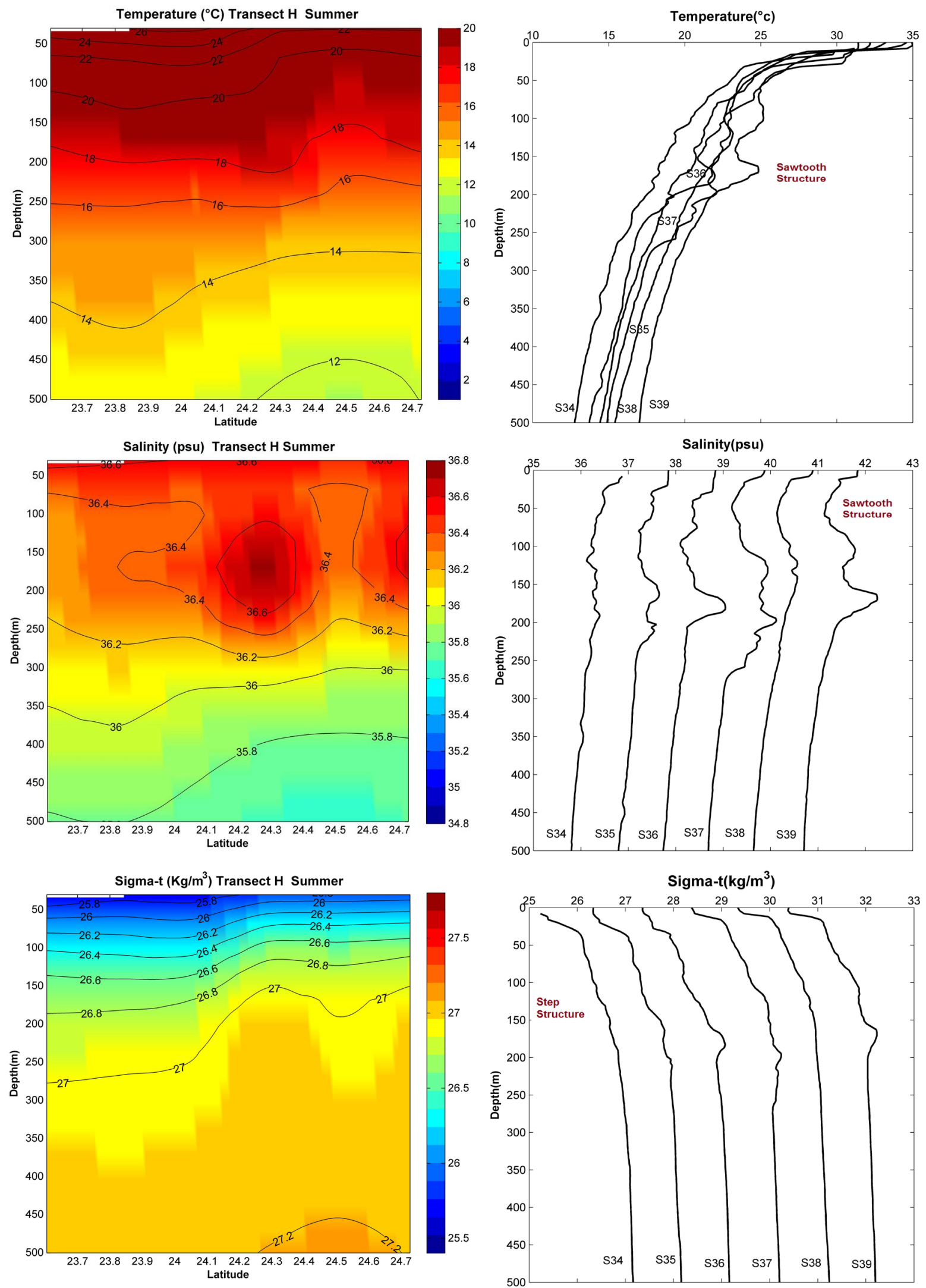

Figure 5. Vertical profiles and the cross-sections of temperature, salinity and potential density from the Persian Gulf outflow for summer 1995 from the transect H shown in Figure 1 for clarification in vertical profiles, one unit has been added to data of stations 35 , two units to data of station 36 etc. 

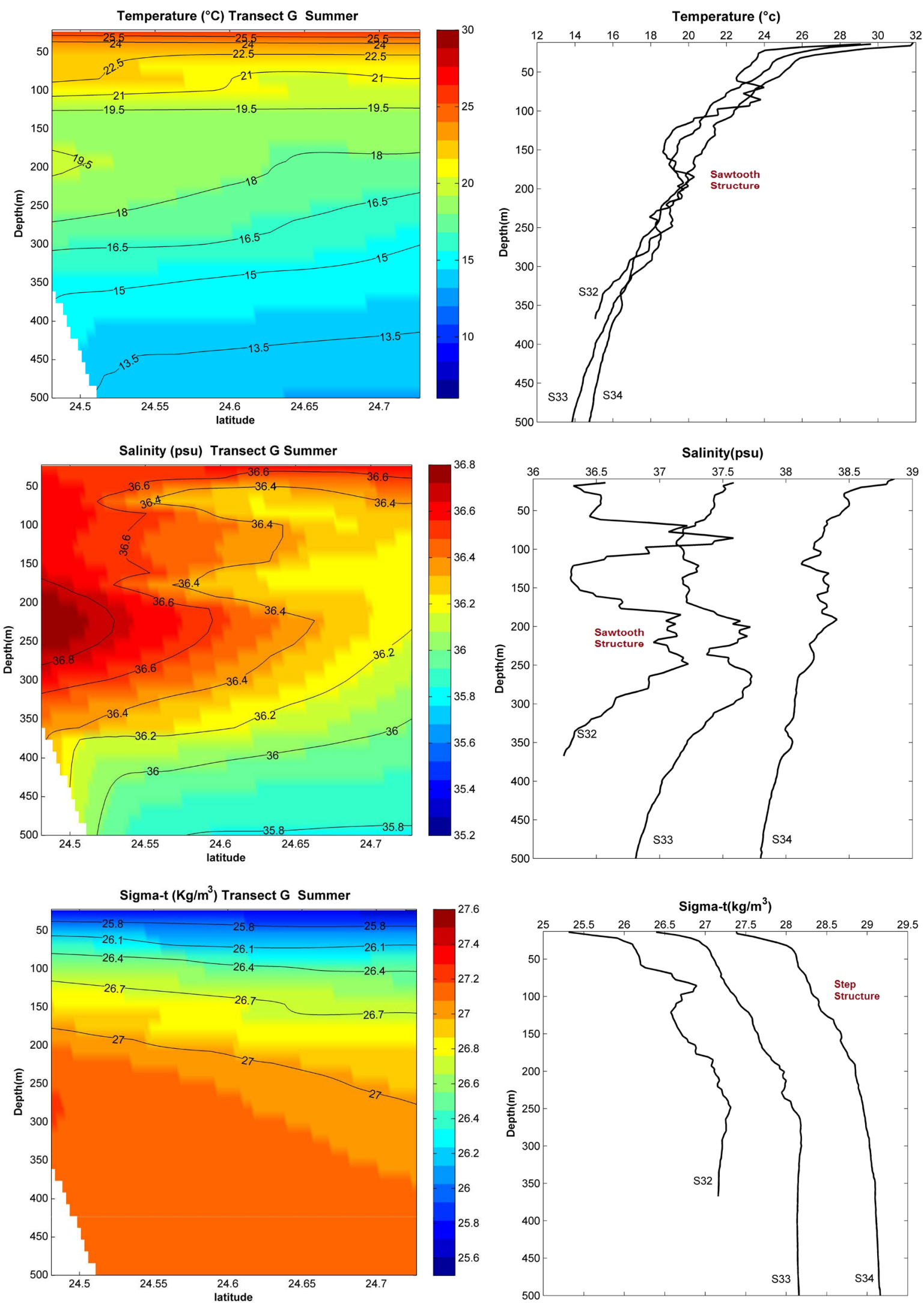

Figure 6. Vertical profiles and the cross-sections of temperature, salinity and potential density from the Persian Gulf outflow for summer 1995 from the transect G shown in Figure 1 for clarification invertical profiles, one unit has been added to data of stations 33 , two units to data of station 34 etc. 
opposed to winter, Persian Gulf outflow that enters into Oman Sea is more unified because thermocline in Oman Sea is stronger than those for other seasons. When thermocline is strong it acts as a lid, and do not allow surface forcing, such as wind or surface buoyancy and eddies reaching low layers, so that the outflow remains less disturbed, hence leading to more intrusive and finger layering. Thick layers $(\sim 50)$ in the outflow may be generated by internal waves generated by the outflow plumes rather than double diffusion convection.

\subsection{Intrusive Layers in Autumn}

Autumn transects L, M and N, as shown in Figure 1, are now analyzed. Figure 7 displays the vertical profiles and the cross-sections of temperature, salinity and potential density in transect $M$ in the Arabesque cruise (Discovery cruise 212, October-November) in 1994. An intrusive thermohaline structure from a depth of $150 \mathrm{~m}$ to $400 \mathrm{~m}$ can be seen in the Oman Sea. In upper 150 meters of Persian Gulf outflow, similar structures due to double diffusive convection can be observed. In vertical profiles of salinity and temperature starting from a depth of $150 \mathrm{~m}$ to a depth of $250 \mathrm{~m}$ diffusive regime is dominant and from a depth of $250 \mathrm{~m}$ to $400 \mathrm{~m}$, salinity and temperature both are reduced, and thermohaline stratification is compatible with salt fingering convection. From this depth, the water column has absolute stratification layer. Cross-section profiles of temperature, salinity and potential density filtered with a cut-off length of $20 \mathrm{~m}$, along the transect $\mathrm{M}$ (Figure 7 ) indicate penetration of lateral intrusion with salinity of $36.8 \mathrm{psu}$ and temperature of $20^{\circ} \mathrm{C}$ and intrusive thermohaline structure lying at 150 400 meter depths, in the frontal zone. Thermohaline intrusion in temperature and salinity profiles have sawtooth while they have step structure in density field. Maximum temperature and salinity in the autumn in the stations studied reaches to $25^{\circ} \mathrm{C}$ and 36.8 psu, and the maximum salinity is in lower depth than the maximum temperature. The thermohaline intrusions are observed along the longitudinal direction of the front, From the Strait of Hormuz to Ra's Al Hadd.

\section{Vertical Interleaving}

The double diffusion regimes with appropriate temperature and salinity gradients are determined by stability ratio or density ratio [18]. $R_{\rho}$ the density ratio is a key index for the study of double diffusion convection and is calculated from $R_{\rho}=\beta \Delta S / \alpha \Delta T$, where $\alpha$ is the thermal expansion coefficient and $\beta$ is the saline contraction coefficient. Density ratio for $R_{\rho}>1$ is favorable to salt fingering, $0<R_{\rho}<1$ is suitable to diffusive convection, $R_{\rho}=0$ refers to a uniform temperature and $R_{\rho}<0$ implies that on both temperature and salinity of stable gradient and there are no diffusion convection. When $R_{\rho}$ reaches about 1 , occur both diffusive convection and salt fingering is likely. In most oceanic regions, $R_{\rho}$ values are very large positive or negative values and are sometimes even extreme, except for subtropical circulation that can have almost a constant value. Problems arise when the $S_{Z}$ (or is too small and the $R_{\rho}$ is related to the $S_{z}$ sign, as in the thermocline $\Theta_{z}$ is almost positive everywhere [8]. In order to make interpretation easier and avoid confusing signs, [19] introduced the Turner angle. 

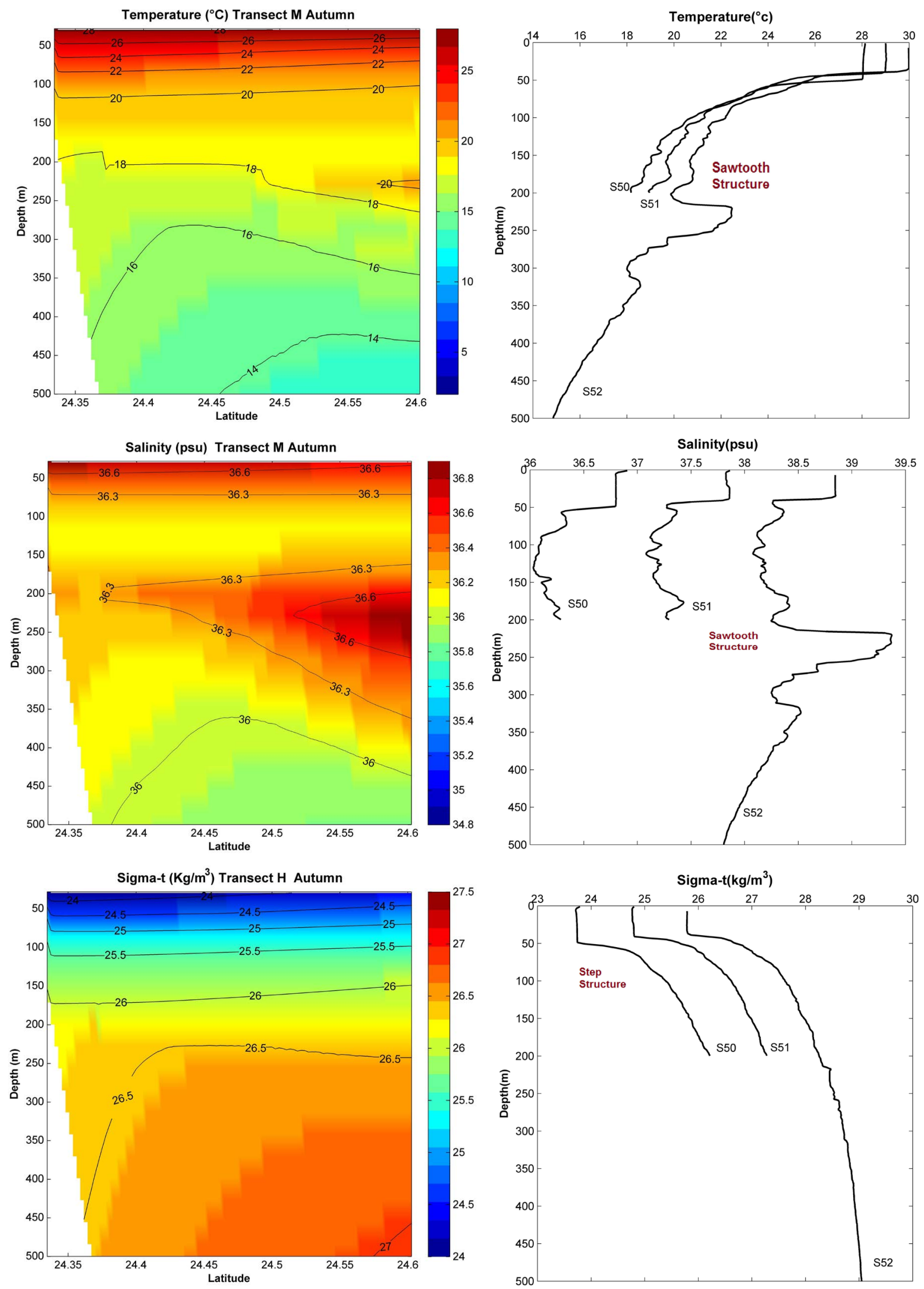

Figure 7. Vertical profiles and the cross-sections of temperature, salinity and potential density from the Persian Gulf outflow for autumn 1994 from the transect M shown in Figure 1 for clarification in vertical profiles, one unit has been added to data of stations 51 , two units to data of station 52 etc. 


$$
\begin{gathered}
T_{u}(\operatorname{deg})=\tan ^{-1}\left(\alpha \frac{\partial \theta}{\partial z}-\beta \frac{\partial S}{\partial z}, \alpha \frac{\partial \theta}{\partial z}+\beta \frac{\partial S}{\partial z}\right) \\
R_{\rho}=-\tan \left(T_{u}+45\right) \\
\alpha=-\rho^{-1} \frac{\partial \rho}{\partial \theta} \\
\beta=-\rho^{-1} \frac{\partial \rho}{\partial S}
\end{gathered}
$$

[19] defined a variable called the Turner angle, $T_{u}=\tan ^{-1}\left(\frac{R \rho+1}{R \rho-1}\right)$, which can be used to show the type of double diffusion convection process. That is if $45^{\circ}<T_{u}<90^{\circ}$ salt fingering (with the extreme case when $T_{u}$ is close to 90) and when $-90^{\circ}<T_{u}<-45^{\circ}$ diffusive convection (with the extreme case when $T_{u}$ is close to -90 ) will occur when $-45^{\circ}<T_{u}<45^{\circ}$ occurrence of double diffusion is impossible, and the water column is doubly stable [8].

All stations of four seasons for the Turner angle and the density ratio are analyzed. Figure 8 shows examples of profiles of Turner angle and density ratio in transects C, D, H, M, stations 3, 16, 35, 48, winter 1992, spring 1996, summer 1995, autumn 1994 respectively. Selected stations for Turner angle and density ratio analysis situate at the shelf break in the Oman Sea. The density ratio is between $1<R_{\rho}<2$ values in depth between $200-500 \mathrm{~m}$, at and below the base of the outflow, that represent both process of double diffusion convection. Based on the profiles of Turner angle it seems that both diffusive and finger convection are possible across the outflow intrusion. Profiles show that in the frontal zone of Oman Sea both processes occur, that have an important role in heat and salinity transfer. Warm and saline lens in these waters with a common diffusive convection on the top layers and salt fingering in bottom layers are expected. Diffusive oscillation between +90 and -90 in the upper layered area, and increase from -90 to -60 in below the outflow is salt finger favorable.

When the temperature gradient is unstable, diffusive convection occurs in the layers and the heat flux is greater than the salt flux. When the salinity gradient is unstable, salt fingering occurs in the layers and in this mode salinity fluxes are higher than the heat flux. Figure 9 and Figure 10 local salinity and temperature gradient profiles show that at the upper interface, the temperature gradient is larger than the salinity gradient therefore diffusive convection is dominant. In the lower interface, both of the temperature and salinity gradient are unstable, so both double diffusive convection and salt fingering occur. The temperature gradient is definitely stronger than the salinity gradient, hence salt fingering is more common. Fine-structures (layers thinner than $20 \mathrm{~m}$ ), while thicker layers are relevant to the other reasons as due to internal waves, as [10] has indicated.

Figure 11 shows T-S diagram of water masses in the frontal zone of outflow intrusion for the four seasons. The changes in temperature, salinity and potential density are respectively in winter 1992 in transect $\mathrm{C}$ shown in Figure $1.18^{\circ} \mathrm{C}-19^{\circ} \mathrm{C}, 37.5 \mathrm{psu}, 26.9$ $\mathrm{kg} / \mathrm{m}^{3}$ in spring 1996 in transect D shown in Figure $1.19^{\circ} \mathrm{C}-21^{\circ} \mathrm{C}, 37.5 \mathrm{psu}, 26.6$ $\mathrm{kg} / \mathrm{m}^{3}$, in summer 1995 in transect $\mathrm{H}$ shown in Figure $1.20^{\circ} \mathrm{C}-22^{\circ} \mathrm{C}, 37 \mathrm{psu}, 25.5$ $\mathrm{kg} / \mathrm{m}^{3}$, in autumn 1994 in transect $\mathrm{M}$ shown in Figure $1.19^{\circ} \mathrm{C}-20^{\circ} \mathrm{C}, 37 \mathrm{psu}, 25.8$ 

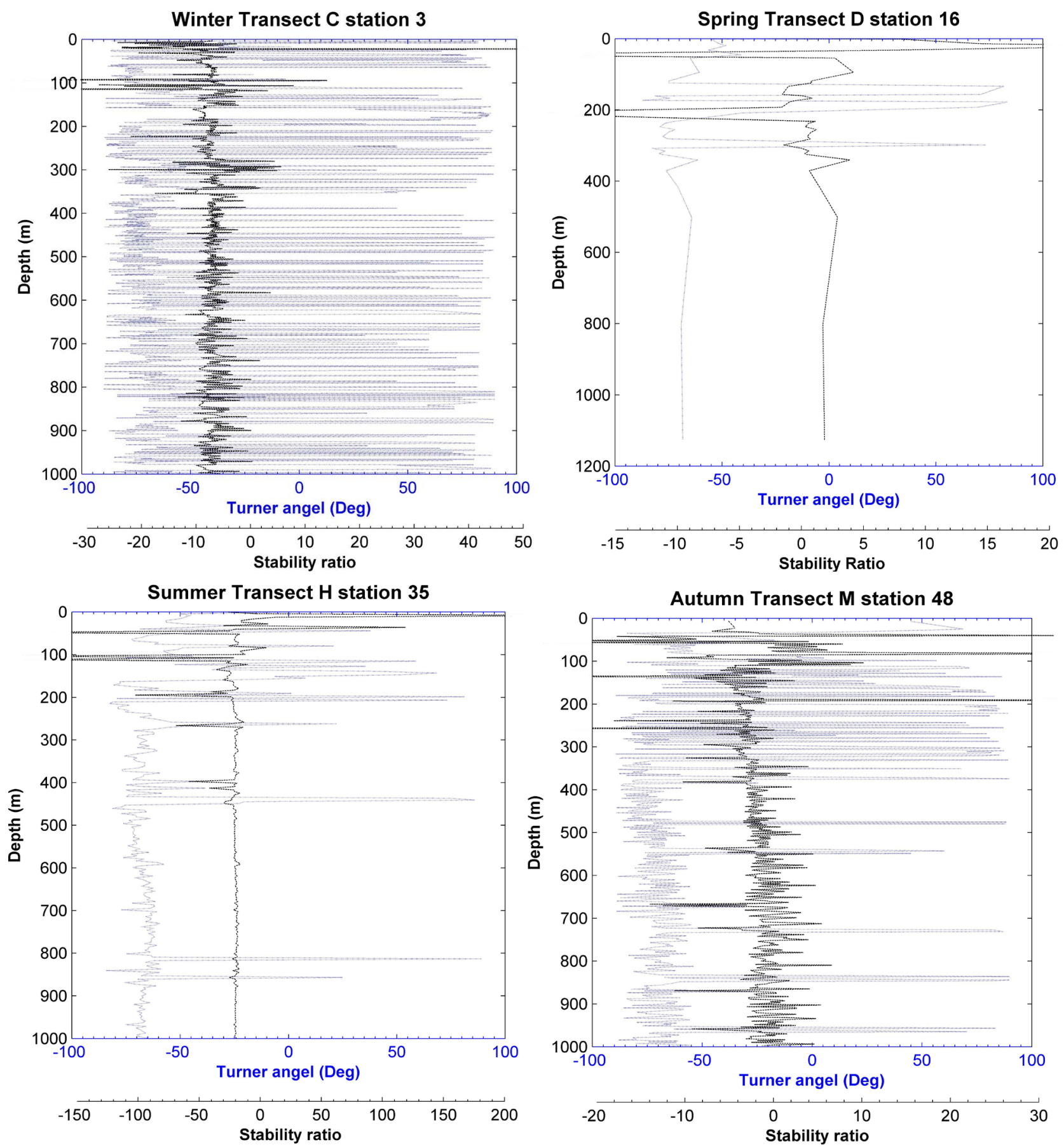

Figure 8. Vertical profiles of Turner angle and density ratio in transects C, D, H, M, stations 3, 16, 35, 48, in winter 1992, spring 1996, summer 1995, autumn 1994, respectively of the Gulf of Oman.

$\mathrm{kg} / \mathrm{m}^{3}$. They can also be seen by comparing the vertical temperature, salinity and potential density profiles described before. All diagrams show a mass of warm and saline water between two cold and fresh water masses. In winter the outflow is at greater depth with respect to other seasons showing higher outflow density in winter [2]-[14]. The T-S diagrams for all seasons in the Oman Sea show the positions of the outflow intrusion with different thicknesses and depths. Variations of the positions of the most salinities in different diagrams are due to changing water masses for different locations 

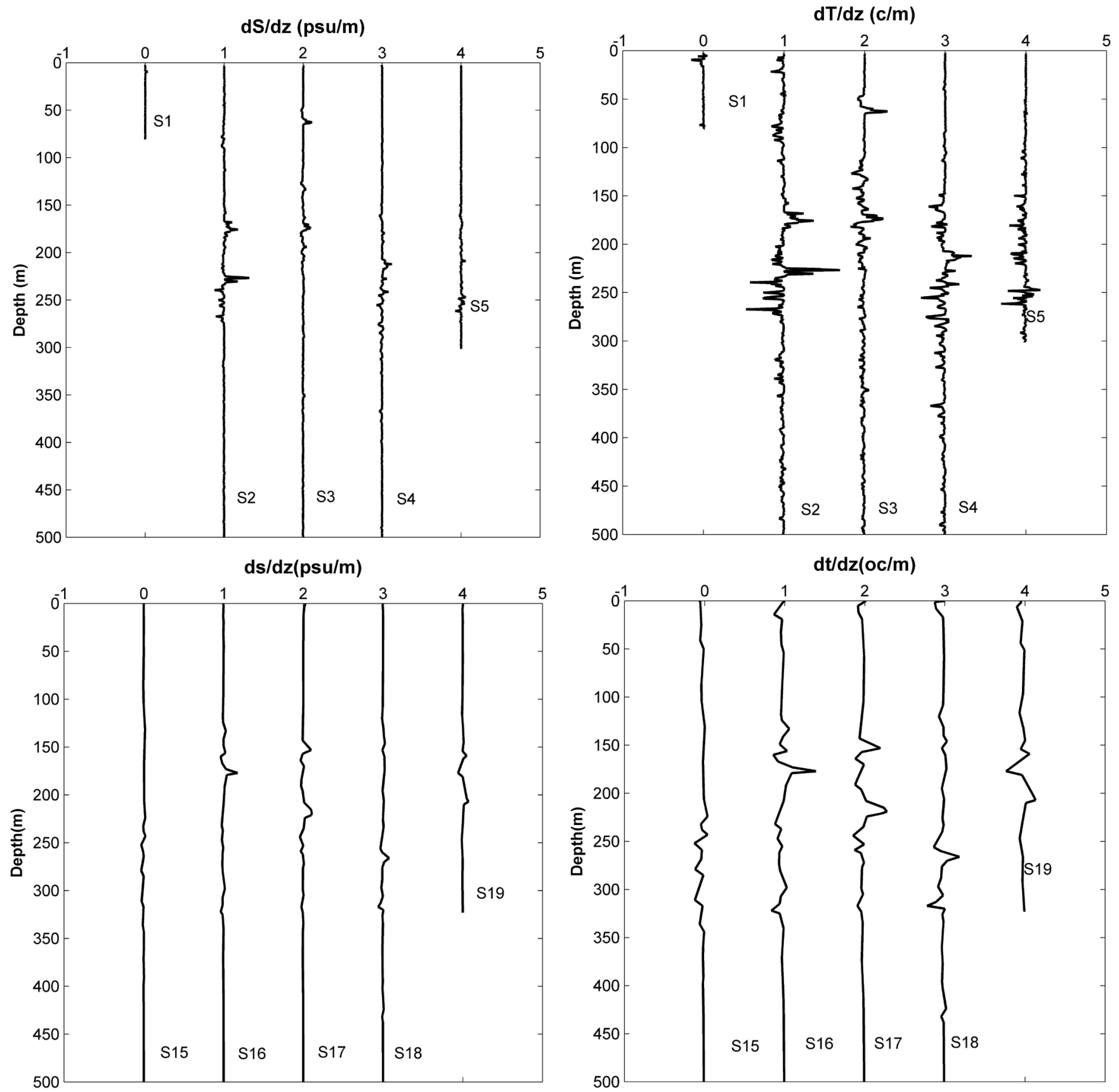

Figure 9. Vertical local gradient profiles of salinity and temperature in top transect C in winter 1992 and in bottom transect D in spring 1996 in the Gulf of Oman.

and depths and paths of intrusive flow. The upper part of the intrusion is susceptible to diffusive layering and the lower part is compatible with salt fingering. At the deeper parts the stratification it is completely stable.

\section{Results and Discussion}

The intrusive layering and thermohaline features observed in the Oman Sea have been described in this study. The analysis has been based on the observational CTD data obtained from different months for years from 1992 to 1996 at frontal zone. Vertical profiles 

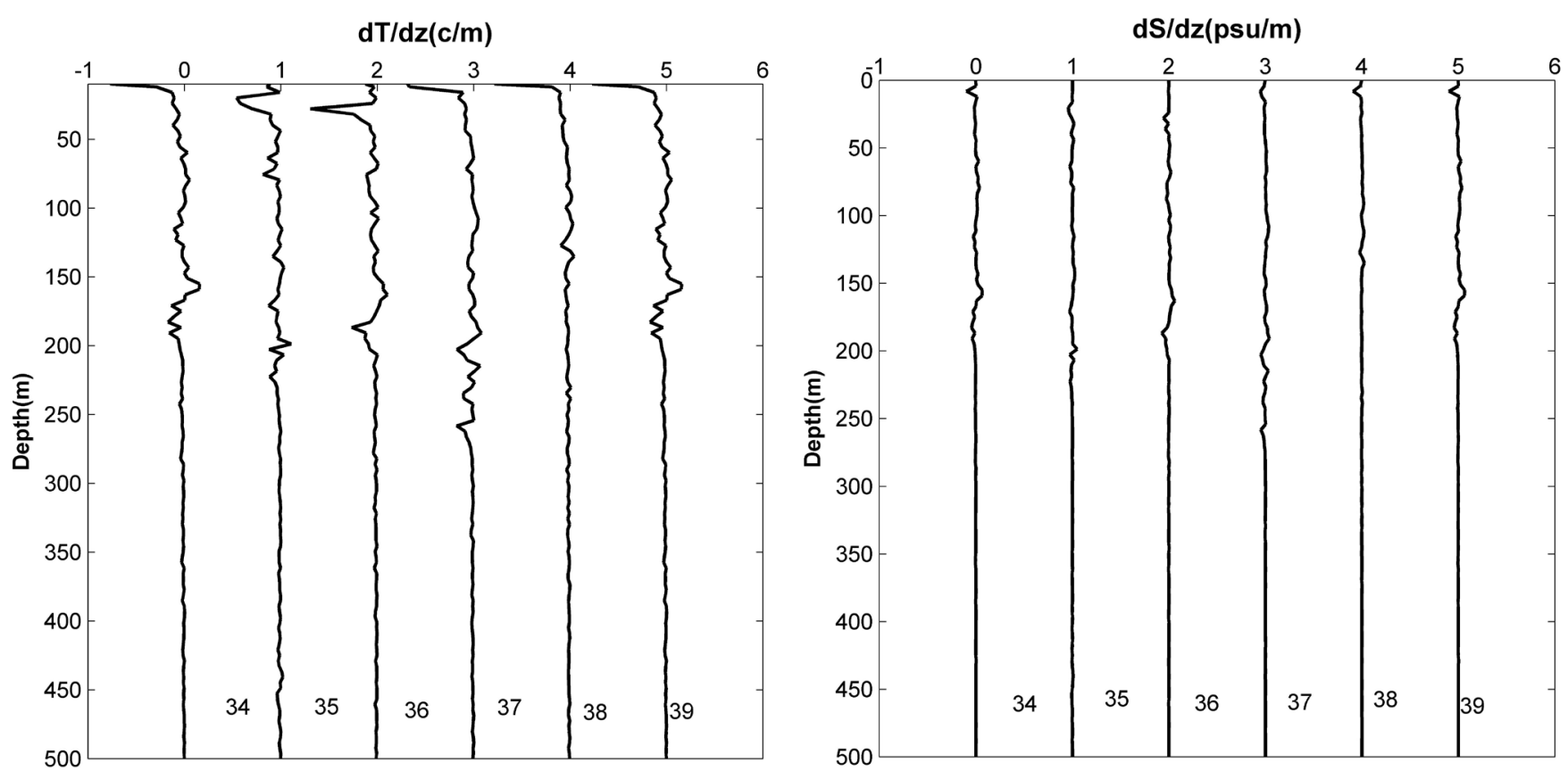

$\mathrm{dT} / \mathrm{dz}(\mathrm{c} / \mathrm{m})$
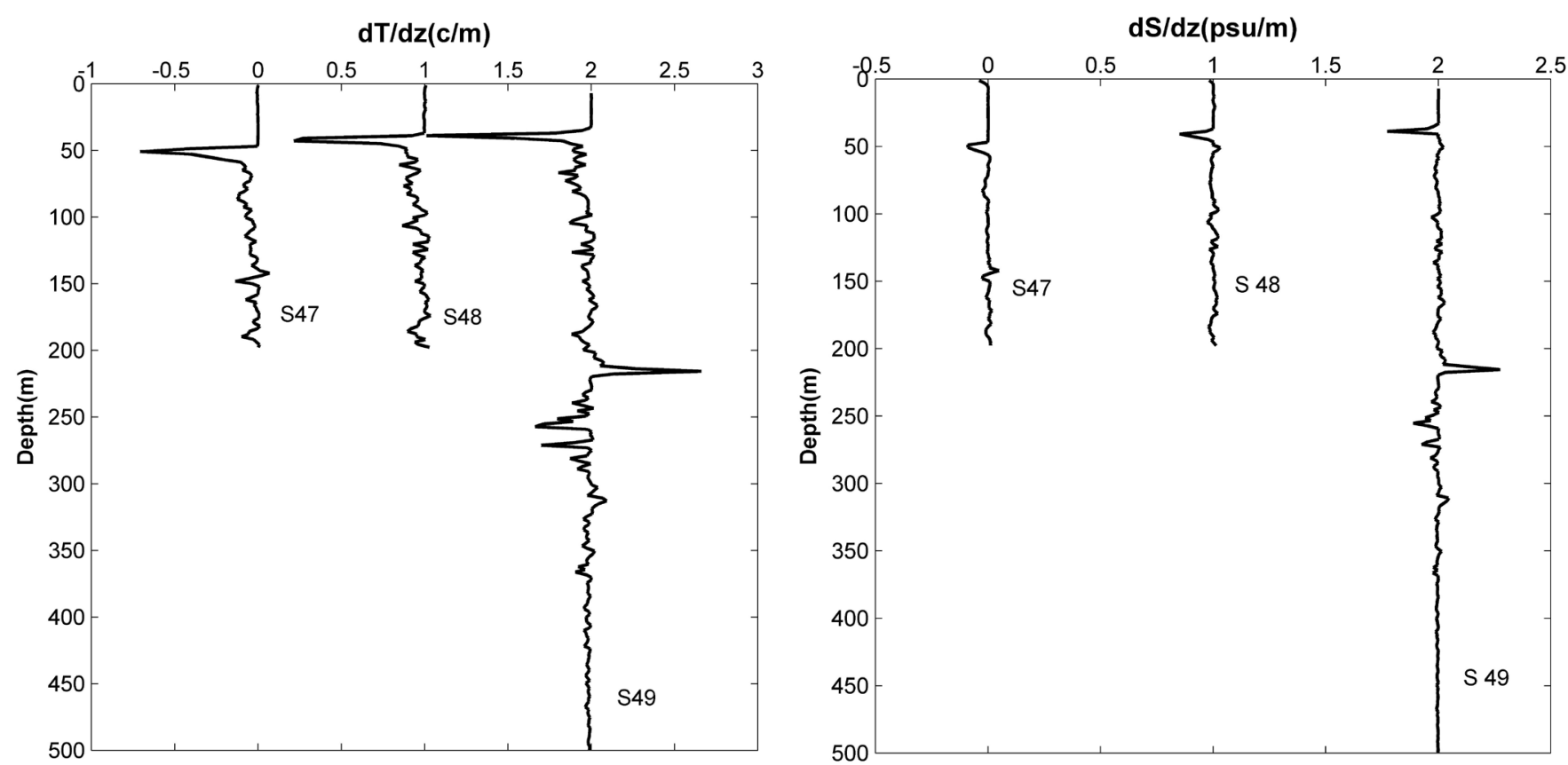

Figure 10. Vertical local gradient profiles of salinity and temperature in top transect $\mathrm{H}$ in summer 1995 and in bottom transect $\mathrm{M}$ in autumn 1994 in the Gulf of Oman.

and the cross-sections of temperature, salinity and potential density in Oman Sea along the Persian Gulf outflow indicate the seasonal variation of vertical extension as well as the depth of the intrusion between the Strait of Hormuz and the Ra's Al Hadd. The thermohaline intrusions observe From the Strait of Hormuz to Ra's Al Hadd, in addition to the southern part of the Gulf to the Iranian coast.

The depths of the intrusive flow with thickness of $250 \mathrm{~m}$, varies between 100 to about $450 \mathrm{~m}$ for different seasons. Changes in winter and spring begin from a depth of about 150 meters, and increase to a depth of 250 to $300 \mathrm{~m}$. In the summer and autumn it 

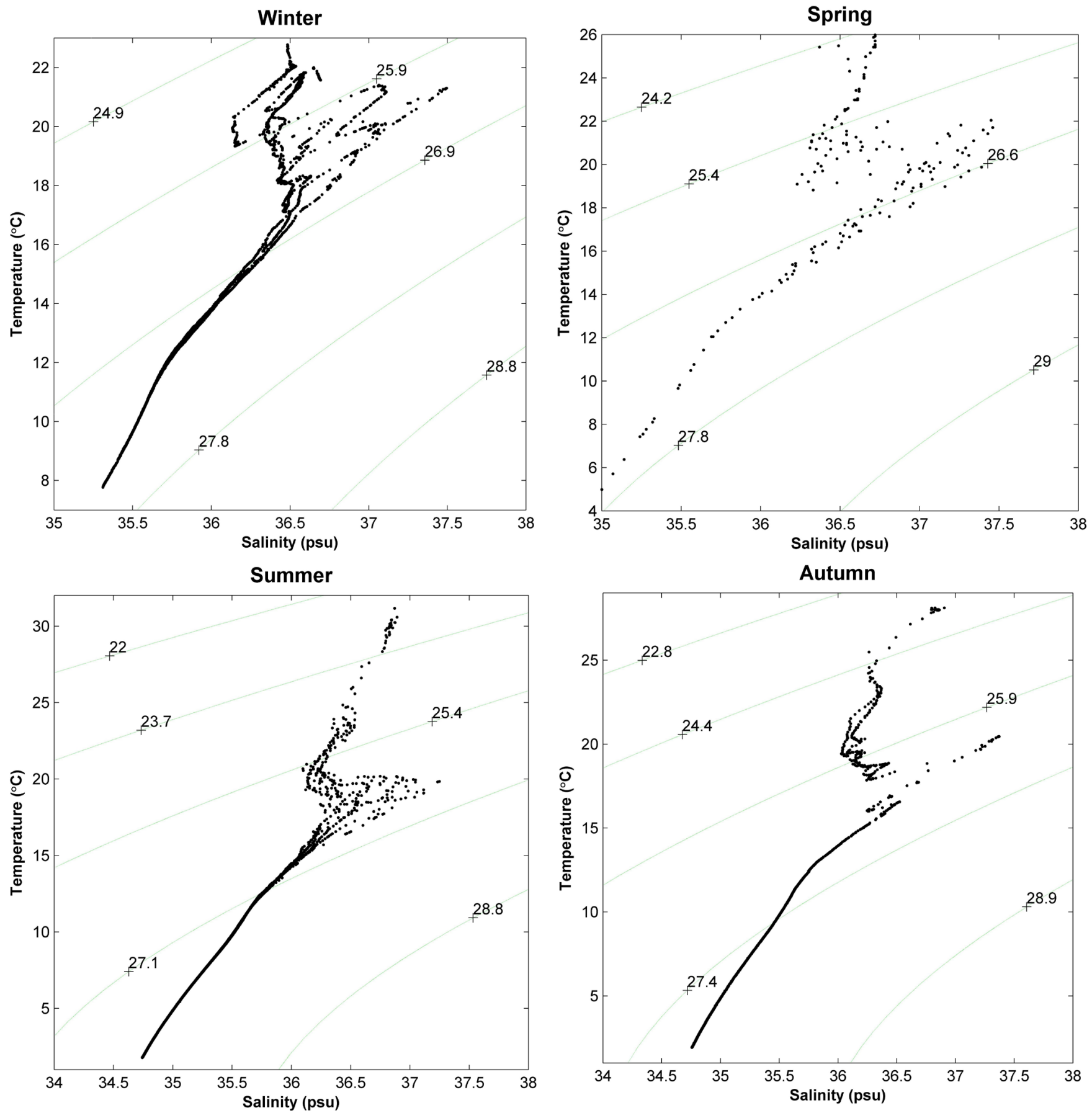

Figure 11. T-S diagrams of water masses in some transects of the Gulf of Oman in four seasons.

starts from 100 and 150 meters depth, and increase to a depth of 250 to $300 \mathrm{~m}$. Whereas in winter the outflow is at greater depth with respect to other seasons showing higher outflow density. In summer, as opposed to winter, Persian Gulf outflow that enters into Oman Sea is more unified because thermocline in Oman Sea is stronger than those for other seasons as [2] has observed.

In the upper 100 and 150 meters of the Persian Gulf outflow, there is colder, less saline water above warmer, saline water and stratification is favorable for the formation of the diffusive convection and diffusive interface. From an average depth of 250 meters 
down to about 450 meters, both salinity and temperature are reduced and the thermohaline stratification is compatible with salt fingering. The unstable salinity gradient has two reasons, the high salinity of the Persian Gulf water entering through Strait of Hormuz and the inflow of cold, low salinity water along the Oman Sea to the Persian Gulf through Strait of Hormuz.

Vertical variation of thermohaline intrusions in profiles of salinity is higher than that in profiles of temperature, as diffusion of salinity is less than the diffusion of temperature. Moreover temperature and salinity steps are detected. Steps thickness is about 10 to 20 meters. The layered structure in temperature has smaller thicknesses than that for the salinity. The salinity maximum is situated deeper than the temperature maximum. This is a result of the unstable stratification. The temperature and salinity profiles in the thermohaline intrusion have sawtooth structures in all stations, except in the density field where they have step structures. More regular intrusive layers observe in the thermocline, and irregular intrusive layer in the shallow depths represent faster interaction in shallower depths. In all stations, the positions of the outflow intrusion show with different thicknesses and depths for all seasons in the Oman Sea. The upper part of the intrusion is susceptible to diffusive layering and the lower part is compatible with salt fingering. At the deeper parts the stratification it is completely stable. Variations of the positions of maximum salinities in different diagrams are due to changing water masses for different locations and depths and paths of intrusive flow. Based on the vertical profiles in the frontal zone of Oman Sea both processes occur (diffusive and finger convection) that have an important role in heat and salinity transfer. Warm and saline lens in these waters with a common diffusive convection on the top layers and salt fingering in bottom layers are expected. Diffusive oscillation between +90 and -90 in the upper layered area, and increase from -90 to -60 in below the outflow is salt finger favorable.

\section{Conclusion}

Persian Gulf outflow enters the Oman Sea with high salinity, these isopycnal waters intrudes into the Oman Sea and creates a tongue of warm and salty water in subsurface, overlying colder and fresher water. At the upper boundary of the PGW outflow, where the temperature gradient is larger than the salinity gradient, diffusive convection is dominant. At its lower boundary, the temperature and salinity gradients are both unstable and both diffusive convection and salt fingering can occur. Convective diffusion rather than salt fingering is the dominant factor in double diffusion of the steady state. Such layered structures have many implications for other processes in these waters. More systematic monitoring of these waters is clearly needed to improve the understanding of these outflow fronts and their seasonal variability.

\section{Acknowledgements}

We would like to thank the Institute of Geophysics, University of Tehran for the freely available observation data in the ROPME expedition during January-February (leg1) and May-June (leg6) 1992 in the Persian Gulf, Sea of Oman and a part of Arabian Sea. We thank the Iranian National Center for Oceanography for providing us the hydro- 
logical data of the Persian Gulf region project from August-September 1995 (INCO2), observation data in the GTSPP project during March-April 1996 in the Arabian Sea,

Gulf of Oman and Arabesque (210-212) project during August-September (210) October November (212) 1994 in the Northwest Indian Ocean, Arabian Sea, Gulf of Oman.

\section{References}

[1] Reynolds, R.M. (1993) Physical Oceanography of the Gulf, Strait of Hormuz, and the Gulf of Oman-Results from the Mt Mitchell Expedition. Marine Pollution Bulletin, 27, 35-59. https://www.researchgate.net/publication/223884087 https://doi.org/10.1016/0025-326X(93)90007-7

[2] Ezam, M., Bidokhti, A.A. and Javid, A.H. (2010) Numerical Simulation of Spreading of the Persian Gulf Outflow in the Oman Sea. Ocean Science, 6, 887-900.

http://www.ocean-sci.net/6/887/2010/ https://doi.org/10.5194/os-6-887-2010

[3] Pous, S.P., Carton, X. and Lazure, P. (2004) Hydrology and Circulation in the Strait of Hormuz and the Gulf of Oman-Results from the GOGP99 Experiment: 1. Strait of Hormuz. Journal of Geophysical Research, 109, 42-56.

http://onlinelibrary.wiley.com/doi/10.1029/2003JC002146/full

https://doi.org/10.1029/2003jc002145

[4] Pous, S.P., Carton, X. and Lazure, P. (2004) Hydrology and Circulation in the Strait of Hormuz and the Gulf of Oman-Results from the GOGP99 Experiment: 2. Gulf of Oman. Journal of Geophysical Research, 109, 57-58.

https://www.researchgate.net/publication/233751515

https://doi.org/10.1029/2003jc002146

[5] Sultan S.A.R. and Elghribi, N.M. (1996) Temperature Inversion in the Arabian Gulf and the Gulf of Oman. Continental Shelf Research, 16, 1521-1544.

https://doi.org/10.1016/0278-4343(95)00086-0

[6] Ruddick, B. and Richards, K. (2003) Oceanic Thermohaline Intrusions: Observations. Progress in Oceanography, 56, 499-527.

http://adsabs.harvard.edu/abs/2003PrOce..56..499R

https://doi.org/10.1016/S0079-6611(03)00028-4

[7] May, B. and Kelly, D. (2001) Growth and Steady State Stages of Thermohaline Intrusions in the Arctic Ocean. Journal of Geophysical Research, 106, 16783-16794.

http://onlinelibrary.wiley.com/doi/10.1029/2000JC000605/full https://doi.org/10.1029/2000JC000605

[8] Bidokhti, A.A. and Griffiths, R.W. (2001) The Role of Internal Waves in the Layering of out Flows from Semi-Enclosed Seas. Proceeding of 14th Australasian Fluid Mechanics Conference, Adelaide, 9-14 December 2001, 885-888.

[9] Radko, T. (2013) Double-Diffusive Convection. Cambridge University Press, Cambridge, 344 p. https://doi.org/10.1017/CBO9781139034173

[10] Bidokhti, A.A. (2005) Shear Induced Splitting of a Plume Outflow in A Stratified Enclosed Basin. Indian Journal of Marine Sciences, 34, 192-211. http://nopr.niscair.res.in/bitstream/123456789/1556/1/IJMS\%2034(2)\%20192-211.pdf

[11] Ruddick, B.R. and Turner, J.S. (1979) The Vertical Length Scale of Double-Diffusive Intrusions. Deep-Sea Research Part A, 26, 903-913.

http://adsabs.harvard.edu/abs/1979DSRA...26..903R https://doi.org/10.1016/0198-0149(79)90104-3

[12] Shcherbina, A.Y., Gregg, M.C., Alford, M.H. and Harcourt, R.R. (2009) Characterizing Thermohaline Intrusions in the North Pacific Subtropical Frontal Zone. Journal of Physical 
Oceanography, 39, 2735-2756. https://doi.org/10.1175/2009JPO4190.1

[13] Kuzmina, N., Rudels, B., Zhurbas, V. and Stipa, T. (2011) On the Structure and Dynamical Features of Intrusive Layering in the Eurasian Basin in the Arctic Ocean, Journal of Geophysical Research, 116, C00D11. https://doi.org/10.1029/2010JC006920 http://onlinelibrary.wiley.com/doi/10.1029/2010JC006920/full

[14] Djoumna, G. and Holland, D. (2014) Spatial and Temporal Patterns of Fine Structure, and Vertical Mixing Processes in Greenland Fjords. Part I: Sermilik Ice Fjord, East Greenland. Journal of Geophysical Research, 10, 1029. http://efdl.cims.nyu.edu/publications/refereed/jgr_mixing_part_2_2015.pdf

[15] Azizpour, J., Chegini, V., Khosravi, M. and Einali, A. (2014) Study of the Physical Oceanographic Properties of the Persian Gulf, Strait of Hormuz and Gulf of Oman Based on PG-GOOS CTD Measurements. Journal of the Persian Gulf, 5, 37-48. http://jpg.inio.ac.ir/article-1-324-en.html

[16] Griffith, R.W. and Bidokhti, A.A. (2008) Interleaving Intrusions Produced by Internal Waves: A Laboratory Experiment. Journal of Fluid Mechanics, 602, 219-239. https://doi.org/10.1017/s0022112008000839

[17] Bower, A.S., Hunt, H.D. and Price, J.F. (2000) Character and Dynamics of the Red Sea and Persian Gulf Outflow. Journal of Geophysical Research, 105, 6387-6414.

http://onlinelibrary.wiley.com/doi/10.1029/1999JC900297/full https://doi.org/10.1029/1999JC900297

[18] Turner, J.S. (1973) Buoyancy Effects in Fluids. Cambridge University Press, Cambridge, 367 p. https://doi.org/10.1017/CBO9780511608827

[19] Ruddick, B.R. (1983) A Practical Indicator of the Stability of the Water Column to DoubleDiffusive Activity. Deep-Sea Research, 30, 1105-1107. https://doi.org/10.1016/0198-0149(83)90063-8

[20] Senjyu, T., Ishimaru, T., Matsuyama, M. and Koike, Y. (1998) High Salinity Lens from the Strait of Hormuz. In: Otsuki, A., Abdulraheem, M.Y. and Reynolds, R.M., Eds., Offshore Environments of the ROPME after the War Related Oil-Spill, TERRAPUB, Tokyo, 35-48.

[21] Wieczorek, G., Hagen, E. and Umlauf, L. (2008) Eastern Gotland Basin Case Study of Thermal Variability in the Wake of Deep Water Intrusions. Journal of Marine Systems, 74, S65-S79. https://doi.org/10.1016/j.jmarsys.2008.07.008

Scientific Research Publishing

\section{Submit or recommend next manuscript to SCIRP and we will provide best service for you:}

Accepting pre-submission inquiries through Email, Facebook, LinkedIn, Twitter, etc. A wide selection of journals (inclusive of 9 subjects, more than 200 journals)

Providing 24-hour high-quality service

User-friendly online submission system

Fair and swift peer-review system

Efficient typesetting and proofreading procedure

Display of the result of downloads and visits, as well as the number of cited articles

Maximum dissemination of your research work

Submit your manuscript at: http://papersubmission.scirp.org/

Or contact ojms@scirp.org 